\title{
The impact of corporate rebranding on brand equity and firm performance
}

\author{
Sohini Nana \\ Rejoice Tobias-Mamina \\ Norman Chiliya \\ Eugine Tafadzwa Maziriri \\ Marketing Division, School of Economic and Business Science \\ University of the Witwatersrand
}

\author{
Keywords \\ Rebranding, Brand Equity, Firm Performance
}

\begin{abstract}
Rebranding has become a very important strategic tool for companies wanting to succeed in this evercompetitive business world using the principles of rebranding. Companies may occasionally discover that they may have to re-position the brand because customers change preferences and new competitors enter the market. Moreover, a strong brand enhances positive evaluations of a product's quality, maintains a high level of product awareness, and provides a consistent image or brand personality. To keep up with fierce competition, companies may seek to transform their business due to changing business directions or adding extra business units. The main purpose of this study was therefore, to investigate the influence of rebranding on brand equity and firm performance. This study was quantitative in nature. Data were collected from 372 respondents using anonymously completed questionnaires. Research scales were operationalised on the basis of previous work. Proper modifications were made in order to fit the research context and purpose. "Rebranding" measure used five-item scales; "Store Layout" used a five item scale measure; "Franchising" used three item measure, "Brand Equity"; " Perceived Quality ", "Brand Associations and Attributes" and "Firm Performance" all used a five item scale measure while "an customer experience" used a six item scale measure. All measurement items were measure on a five-point Likert-type scale that was anchored by $1=$ strongly agree to $5=$ strongly disagree to express degree of agreement. The seven posited hypotheses were empirically tested.

The results supported three hypotheses in a significant way and rejected four hypotheses. Important to note about the study findings is the fact that rebranding has no effect on the firm's brand equity although brand equity has an influence on the firm's performance. Notably too, the relationship between customer experience and firm performance is robust. This finding indicates that brand equity can have a strong influence without the influence of rebranding. A major implication for this study is that rebranding is a risky operation that needs to be carefully managed.
\end{abstract}

Corresponding author: Eugine Tafadzwa Maziriri

Email addresses for the corresponding author: eugine.maziriri@gmail.com

First submission received: $7^{\text {th }}$ October 2018

Revised submission received: 30 th January 2019

Accepted: $2^{\text {nd }}$ April 2019

\subsection{Introduction}

In today's day and time, tremendous emphasis is placed on moving from line branding to corporate branding. The management approach for corporate branding needs to be better appreciated as it differs from line branding (Harris \& Chernatony, 2001). The need for rebranding has become an important marketing and strategic tool for corporations wanting to succeed in this ever-competitive business world (Moisescu \& Vu, 2011). Re-positioning a brand occurs when customer preference changes arise, and new competitors enter the market. Having a strong brand enhances positive evaluations of a product's quality, maintains a high level of product awareness, and provides a consistent image or brand personality (Petburikul, 2009). Revitalising and repositioning a brand though progressive modification of the brand proposition in a total aesthetic experience, can be considered an expected undertaking of brand 
management in response to changing market conditions. This paper focuses on the phenomenon of rebranding, as evidenced by a change of store image, and its influence on brand equity and business performance. It sets out to understand the drivers of the firm performance phenomenon and to analyse the impact of rebranding strategies on corporate equity and performance of an SME within the fast food industry in South Africa.

The activities of SME enterprises in South Africa are of fundamental importance for the promotion of economic growth, job creation and poverty alleviation. In South Africa, it is estimated that $91 \%$ of the formal business entities are SME's. These contribute 52 to $57 \%$ of the GDP and 61\% to employment (Abor \& Quartey, 2010). Previous authors have researched on the fast food industry in various contexts by focusing on corporate social responsibility (Schrempf, 2014); media character branding (Dixon, Niven, Scully \& Wakefield, 2017) and effect of social media advertisements on brand equity (Hanaysha, 2016).

Premised on the identified research gap, the current study seeks to investigate the influence of rebranding strategies on brand equity and firm performance in South Africa's fast food industry. Above all, the current study is expected to make academic and practical contributions to the existing branding literature and practice of rebranding in developing countries, particularly in South Africa.

\section{Research context}

The growth of SME's (small to medium enterprises) in a highly competitive, low margin market, coupled with continuously increasing raw costs and fuel costs, is proving to be a challenge with which many businesses are faced (Lee et al., 2016). The SME is simply unable to compete in a market that is dominated by well-established high-volume manufacturers. The general South African consumer is brand driven, price conscious, as well as quality and service orientated. The South African food industry specifically, is a mine field where the consumer is spoilt for choice. If the SME does not tick all the boxes, they simply cease to exist and hence the reason for failure is due to the inability and inexperience of the owners (Standard Bank, 2014).

The SME under current study specialises in savory snacks. Being a family owned business and remotely managed operation consisting of 54 retail stores, poses many hurdles. Uniformity and consistency in corporate identity, in-store day-to-day retail management, poor customer service, lack of mentorship, KPI analysis and training and inconsistencies in quality are issues which are resulting in the degradation of the overall brand equity and retardation of the brand's performance (Lee et al., 2016). However, this can be remedied through universal rebranding; franchising; setting and evaluating of the key performance indicators; soliciting the service of mystery shopper to assess service level and internal customer motivation.

The food outlet under study is fully funded and solely grown by its own internal retail net profit pool. Due to high fuel cost constraints and poor retail management, it is simply not economically viable to distribute products to all its outlets across the country. Furthermore, landlords in the mainstream retail sector simply do not want to carry the risk of having to lease out their retail space to marginally established SME's. These factors impact on the firm's market share. In the light of the above, this study seeks to determine if the rebranding efforts have improved firm performance.

\subsection{Conceptual model and hypothesis development}

A conceptual model describes the relationship between variables investigated in the study (Maziriri and Chuchu, 2017; Maziriri, Mapuranga \& Madinga, 2018). In order to empirically test the interrelationships between store layout and franchising on rebranding; perceived quality and brand association and attributes on brand equity, customer experience and firm performance, a conceptual model is developed, premised on the reviewed marketing and particularly, brand management literature. In this conceptualised model, firm performance is the single outcome variable. Figure 1 illustrates this conceptualised research model. The hypothesised relationships between the research constructs is subsequently discussed. 


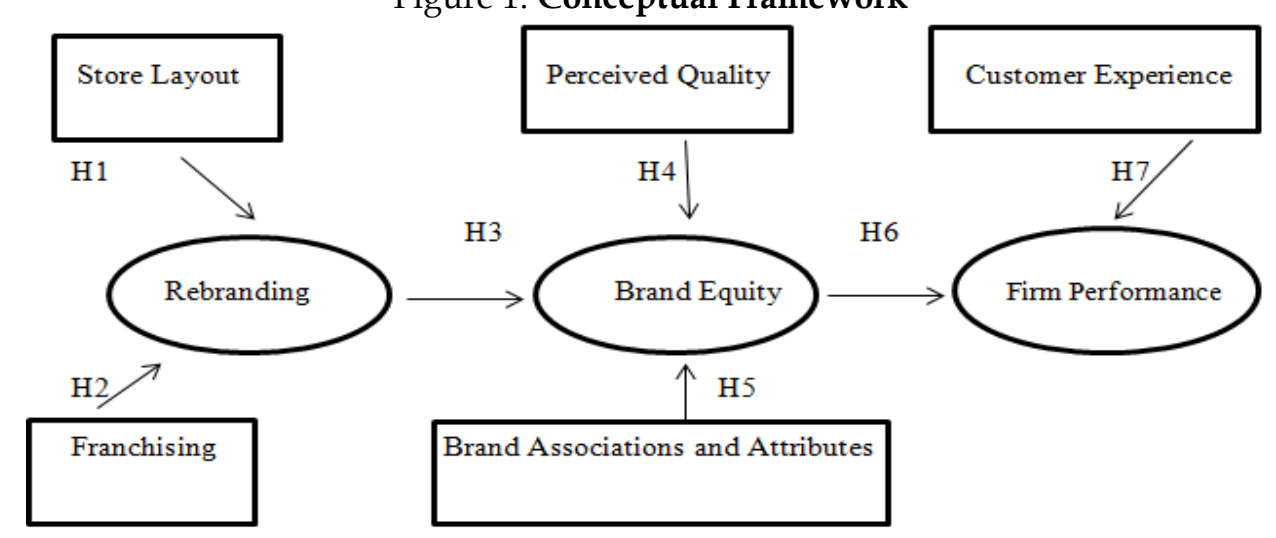

This section derives hypotheses from the conceptual framework shown in Figure 1. This article argues that store layout and franchising influence customers' perception about a rebranded firm with which they deal, leading them to associate their perceptions with the brands they intend to purchase, thus developing brand equity, resulting in positive firm performance.

\subsection{Store Layout and Rebranding}

Store layout is considered a fundamental factor that drives consumer movement and purchase reaction (Ghosh et al., 2010). Currently, companies tend to focus on creating a reverberating store image instead of evolving the image of products. The emblematic, observed expression of the way consumers "picture" or "visualise" a store, is by the store image (Saraswat, et al., 2010). Once the customers experience and adopt the image, there is a clear reason to understand that once the consumers are likely to feel comfortable, consumers will begin to accept the store which is in sync with their lifestyle, purchase the items that reflect their taste and necessities of what they wish to eat, wear, give to others, and furnish their homes with (Saraswat, et al., 2010). Therefore, store image provides value-added benefits to the consumers. Layout is an important factor in rebranding as it influences both the customer experience and the speed of shopping (Ghosh et al., 2010). Based on the literature, the relationship between store layout and rebranding is hypothesised as follows:

H1: Change in store layout has a positive influence on rebranding.

\subsection{Rebranding and franchising}

The need for rebranding has become an important marketing and strategic tool for corporations wanting to succeed in this endlessly competitive business world (Moisescu \&Vu, 2011). With regards to the literature on brand management, rebranding strategies have received limited academic attention (Plewa, et al., 2011). Rebranding is a marketing transformation practice that can be defined and characterised in different ways (Plewa, et al., 2011). It entails changing a business's name, targeting and repositioning the business offerings to its consumers and communities (Opuni \& Baffoe, 2013). The primary goal for rebranding is to replicate a change in the business and to foster a new image, hence it is a proposition for innovation and development (Muzellec \& Lambkin, 2006). Therefore, it can be postulated that:

\section{H2: Franchising has a positive influence on rebranding.}

\subsection{Rebranding and brand equity}

The content and significance of brand equity has been a focus of debate in various ways and for several diverse purposes with no common viewpoint emerging (Keller, 2003). Brand equity can be examined from a firm, retailer and consumer perspective. Firms, retailers and investors have very different perspectives of brand equity, hence the different methods of measuring brand equity. While manufacturers and retailers are interested in the strategic implications of the brand equity, investors are more concerned with the financially defined concept. Proponents of the financial perspective consider brand equity as the incremental cash flows which accrue to branded products over unbranded products (Farjam \& Hongyi, 2015). The customer-based perspective is content that the power of a brand lies in the brand knowledge, resulting from customers' interaction and experiences with the brand over time (Keller, 
2003), similar to the way large firms sometimes overhaul their brand images and re-launch themselves as fresh corporate brands, just as food outlets sought to establish entirely new brand identities. As a result, when considering rebranding, organisations need to rethink the image and positioning of the brand in a way which will not create confusion in consumers' minds (Hankinson, 2015). Therefore, based on the foregoing discussion, this study posits that:

H3: Rebranding has a positive influence on brand equity.

\subsection{Perceived Quality and brand equity}

Different conceptualisations of brand equity have been posited in extant literature (Aaker,1991, Aaker \& Joachimsthaler, 2000). This article adopts Aaker (1991)'s conceptualisation and defines brand equity as a multi-factor structure that contains brand loyalty, brand awareness, brand knowledge, customer satisfaction, perceived equity, brand associations, and other proprietary assets. Perceived quality can be defined as the general perception of customers about intensity and quality of products or services in comparison with competing offerings (Aaker, 1996). However, Erenkol and Duygun (2010) argue that product quality and perceived quality is not synonymous, since perceived quality is a consumer or buyer's subjective assessment of the product, although perceived quality is a key determinant of consumer's choice and is positively related to brand equity. Therefore, perceived quality is a competitive prerequisite and several businesses presently have turned customer-driven quality into an effective strategic weapon. Extant literature draws attention to the intimate relationship between product quality, customer satisfaction and business profitability. Therefore, customers' positive perceptions of brand quality lead to continuous purchase of the same brand chosen from consumers' evoked set (Jin, Lee, \& Huffman, 2012). Based on the aforementioned discussion and empirical evidence, it can be hypothesised that

H4: Perceived quality has a positive influence on brand equity.

\subsection{Brand Attributes, Brand Associations and Brand Equity}

In order to create a positive brand image, it requires marketing programmes that link strong, favourable, and unique associations to brand memory. A brand association is the utmost recognised characteristic of brand equity (Leh \& Lee, 2011). A brand association comprises all brand related thoughts, feelings, perceptions, images, experiences, beliefs, attitudes and is everything connected in memory to a brand (Kotler \& Keller, 2006). Associations embody the basis for purchase decision and for brand loyalty (Fayrene \& Lee, 2011) and act as information collecting tools to execute brand differentiation and brand extension (Aaker, 1996). Furthermore, brand image can be viewed as the functional attribute of the product or service which make consumers reflect their self-image and which assists when making purchase decisions (Aghekyan-Simonian et al., 2012). In addition, the extant branding literature indicates that products with stronger brand image can diminish consumers' cognitive risk (Kwon \& Lennon, 2009). In this respect, consumers often exploit the sense of brand image to infer the quality of the product or service and make decisions (Salinas \& Pérez, 2009). Consequently, the quality of the brand image indirectly causes consumers' perception of the product or service quality. In addition, utilising the ideal brand image not only assists businesses to establish market positions, but also protects brands from competition (Cretu \& Brodie, 2007). As result, businesses nowadays labour to retain their brand image and therefore invest significant resources to develop names with a favourable image (Keller, 2017). Based on the aforementioned discussion, this study posits that

H5: Brand attributes and associations have a positive influence on brand equity.

\subsection{Brand equity and Firm performance}

Organisational performance is the most important criterion in evaluating organisations, their actions, and environments (Cameron \& Whetten, 2013). In today's vibrant and swiftly altering workplace and macro economy, expansion of organisational performance relates to the improvement in personal performance, skills, knowledge and experience (Al-Khouri, 2013). High brand equity induces customers to pay a premium price for the product or service and to engage in favourable word of mouth regarding the firm and its products, therefore enhancing its brand performance (Beverland et al., 2007). Several studies found that brand equity has a "halo effect", transferring brand evaluation from one category to another and that buyers were willing to pay a premium price, as well as prepared to buy and recommend 
products with the same brand name (Hutton, 1997; Bendixen et al., 2004). Therefore, it can be hypothesised that:

H6: Brand equity has a positive influence on firm performance.

\subsection{Customer experience and firm performance}

Meyer and Schwager (2007) define customer experience as the core and subjective response customers have to any interaction with a business. The prevalence of positive customer experiences provides an opportunity for long-term competitive advantage to the firm and subsequently results in loyalists who pass on positive word-of-mouth (Wali et al., 2015). Based on the aforementioned, it can be hypothesised that:

H7: Customer experience has a positive influence on firm performance.

\subsection{Research design and methodology}

\subsection{Sample and data collection}

The target population for the study was the South African consumer in Gauteng who falls within the lower LSM and the middle LSM levels. The sampling unit was the individual consumer. A customer intercept survey was used. This method has the advantage of speed, is less costly, and the researcher has control over respondent type. Four outlets of this particular retail outlet in Gauteng were selected for this survey. Students from the University of the Witwatersrand were recruited as research assistants to distribute and collect the questionnaires.

Of the total of 385 surveys questionnaires distributed, 372 usable questionnaires were retrieved for the final data analysis, representing a response rate of 96 per cent. To eliminate differences in response patterns due to different reference points, all respondents were prompted to answer the questionnaire with reference to a SME which specialises in savory snacks. The reason for selecting this category was that consumers frequently purchase snacks from SME retail outlets. In this regard, the respondents were asked to identify retail outlets within the SME category which sell savory snacks with the aid of pictures. Respondents were then asked to name the retail brand and were requested to think about that brand as they completed the entire questionnaire, guided by the research assistants.

\subsection{Measurement instrument and questionnaire design}

Research scales were operationalised based on previous work. Proper modifications were made in order to fit the current research context and purpose. All the measurement items were measured on a fivepoint Likert-type scale that was anchored by $1=$ strongly disagree to $5=$ strongly agree to express the degree of agreement.

\subsection{Data Analyses and results}

\subsection{Sample description}

Table 1 represents the demographic information of the participants. The respondents were predominantly female $(57.5 \%)$. The average age group of the respondent was that of less than 45 years (83 per cent). About 22 per cent of the respondents were students, 70 per cent were either formally employed or self-employed. Most of the respondents were customers of the outlet before the rebranding phase.

Table 1: Sample demographic profile

\begin{tabular}{|l|l|l|}
\hline & Frequency & $\%$ \\
\hline Gender & & \\
\hline Male & 158 & 42.5 \\
\hline Female & 214 & 57.5 \\
\hline Age & & \\
\hline$\leq 25$ & 113 & 30.4 \\
\hline $26-45$ & 193 & 51.9 \\
\hline$\geq 45$ & 66 & 17.7 \\
\hline Occupation & & \\
\hline Student & 80 & 21.5 \\
\hline Self-employed & 64 & 17.2 \\
\hline Employed & 195 & 52.4 \\
\hline Unemployed & 113 & 30.4 \\
\hline Have you been a customer before rebranding? & 307 & \\
Yes & 32.5 \\
No & 65 & $\mathbf{1 7}$ \\
\hline
\end{tabular}




\subsection{Measurement accuracy assessment}

The researcher tested the measurements reliability and validity. Reliability was primarily checked using the composite reliability (CR) and Cronbach's a value. To certify convergent validity, the researcher checked if items loaded on their respective (a priori) constructs with loadings greater than 0.5, while discriminant validity was checked by average variance extracted (AVE) value and making certain that there was no considerable inter-research variables cross-loadings (Chin, 1998). Structural Equation modelling (AMOS-24) performs a confirmatory factor analysis (CFA) while estimating the structural model (SEM). The CFA results are detailed in Table 2, while the SEM results are presented in Table 3.

As indicated on Table 2, all items (except RB2- 0.492) have loadings greater than 0.5 (Nunnally \& Bernstein, 1994), indicating that they explain at least 50 per cent of what they expected to measure (convergent validity). The lowest AVE value is 0.492 which is approximately equal to the recommended 0.5 (Fornell \& Larcker, 1981) - an indication of the existence of discriminant validity. Nevertheless, to guarantee adequate discriminant validity between the research constructs, the square root of the AVE of each factor should exceed the correlations between that factor and all other factors (Fornell \& Larcker, 1981). In this study, the least squared root of AVE is 0.782, confirming the existence of discriminant validity. Using the $C R$ value and Cronbach's a value, the measurement instrument's reliability was calculated, and lowest values are 0.779 and 0.764, respectively, which exceeds the recommended acceptable value of 0.7 (Nunnally \& Bernstein, 1994). These results confirm the reliability and validity of the measurement used in this study.

Overall acceptable CFA model fit indices used in this study included $\chi^{2}(\mathrm{df})$ value equal to or less than 3.00, Comparative Fit index value equal to or higher than 0.8 and RMSEA value equal or less than 0.08. Recommended statistics for the overall model assessment indicated an acceptable fit of the measurement model to data. The rebranding model provides RMR value of 0.06; CFI value 0.837; RMSEA value 0.074 indicating good model fit.

Table 2: Accuracy analysis statistics

\begin{tabular}{|c|c|c|c|c|c|c|c|c|c|c|}
\hline \multirow{2}{*}{\multicolumn{2}{|c|}{$\begin{array}{l}\text { Research } \\
\text { Construct }\end{array}$}} & \multicolumn{4}{|c|}{ Descriptive Statistics } & \multicolumn{2}{|c|}{$\begin{array}{l}\text { Cronbach's } \\
\text { Test }\end{array}$} & \multirow[t]{2}{*}{$\begin{array}{l}\text { C.R. } \\
\text { Value }\end{array}$} & \multirow[t]{2}{*}{$\begin{array}{l}\text { AVE } \\
\text { Value }\end{array}$} & \multirow[t]{2}{*}{$\begin{array}{l}\text { Factor } \\
\text { Loading }\end{array}$} \\
\hline & & \multicolumn{2}{|c|}{ Mean Value } & \multicolumn{2}{|c|}{$\begin{array}{l}\text { Standard } \\
\text { Deviation }\end{array}$} & $\begin{array}{l}\text { Item- } \\
\text { total }\end{array}$ & $\begin{array}{l}\text { a } \\
\text { value }\end{array}$ & & & \\
\hline \multirow[t]{4}{*}{ RB } & B2 & 4.51 & \multirow[t]{4}{*}{4.408} & 0.691 & \multirow[t]{4}{*}{0.724} & \multirow[t]{4}{*}{4.000} & \multirow[t]{4}{*}{0.781} & \multirow[t]{4}{*}{0.786} & \multirow[t]{4}{*}{0.608} & 0.492 \\
\hline & B3 & 4.38 & & 0.744 & & & & & & 0.645 \\
\hline & B4 & 4.37 & & 0.756 & & & & & & 0.829 \\
\hline & B5 & 4.37 & & 0.705 & & & & & & 0.777 \\
\hline \multirow[t]{4}{*}{ SL } & B6 & 4.37 & \multirow[t]{4}{*}{4.205} & 0.71 & \multirow[t]{4}{*}{0.733} & \multirow[t]{4}{*}{4.000} & \multirow[t]{4}{*}{0.782} & \multirow[t]{4}{*}{0.789} & \multirow[t]{4}{*}{0.614} & 0.737 \\
\hline & B7 & 4.31 & & 0.663 & & & & & & 0.763 \\
\hline & B8 & 3.93 & & 0.857 & & & & & & 0.631 \\
\hline & B9 & 4.21 & & 0.702 & & & & & & 0.647 \\
\hline \multirow[t]{2}{*}{ F } & B12 & 3.9 & \multirow[t]{2}{*}{3.810} & 1.102 & \multirow[t]{2}{*}{1.130} & \multirow[t]{2}{*}{2.000} & \multirow[t]{2}{*}{0.860} & \multirow[t]{2}{*}{0.904} & \multirow[t]{2}{*}{0.884} & 0.696 \\
\hline & B13 & 3.72 & & 1.157 & & & & & & 1.085 \\
\hline \multirow[t]{5}{*}{$\mathrm{BE}$} & $\mathrm{C} 1$ & 4.01 & 4.032 & 0.902 & 0.804 & 5.000 & 0.838 & 0.841 & 0.645 & 0.659 \\
\hline & $\mathrm{C} 2$ & 4.16 & & 0.732 & & & & & & 0.701 \\
\hline & $\mathrm{C3}$ & 4.06 & & 0.737 & & & & & & 0.715 \\
\hline & $\mathrm{C} 4$ & 4.03 & & 0.794 & & & & & & 0.694 \\
\hline & $\mathrm{C5}$ & 3.9 & & 0.856 & & & & & & 0.812 \\
\hline $\mathrm{PQ}$ & $\mathrm{C} 6$ & 4.27 & 4.098 & 0.678 & 0.759 & 5.000 & 0.767 & 0.780 & 0.539 & 0.662 \\
\hline & $\mathrm{C} 7$ & 4.32 & & 0.694 & & & & & & 0.729 \\
\hline & $\mathrm{CB}$ & 4.08 & & 0.77 & & & & & & 0.561 \\
\hline & $\mathrm{C9}$ & 3.86 & & 0.816 & & & & & & 0.596 \\
\hline & $\mathrm{C} 10$ & 3.96 & & 0.838 & & & & & & 0.668 \\
\hline BAA & $\mathrm{C} 11$ & 4.12 & 4.076 & 0.723 & 0.749 & 5.000 & 0.764 & 0.7791 & 0.538 & 0.71 \\
\hline & $\mathrm{C} 12$ & 4.19 & & 0.62 & & & & & & 0.699 \\
\hline & $\mathrm{C} 13$ & 4.3 & & 0.735 & & & & & & 0.652 \\
\hline & C14 & 3.76 & & 0.872 & & & & & & 0.511 \\
\hline & C15 & 4.01 & & 0.796 & & & & & & 0.636 \\
\hline
\end{tabular}

NOTES: RB Rebranding; $\mathrm{SL}=$ Store Layout; F= Franchising; $\mathrm{BE}=$ Brand Equity; $\mathrm{PQ}=$ Perceived Quality; $\mathrm{BAA}=$ Brand Attributes \& Associations

Scores: 1- strongly Disagree; 3- Neutral; 5- Strongly Agree 


\subsection{Research model assessment and research hypothesis testing}

In this study, structural equation modelling (SEM-AMOS 24) was used to test the posited hypotheses in the conceptual research mode (Ringle et al., 2005). A two-step procedure was applied to analyse the research data, as suggested by Anderson and Gerbing (1988). Accuracy of multi-item construct measures was followed by the test of the research model and hypotheses.

The results in Table 3 provide support for three of the seven hypotheses. H1 posited a positive relationship between Store Layout and rebranding, $\mathrm{H} 2$ posited a negative relationship between Franchising and rebranding; H3 posited a negative relationship between Rebranding and Brand Equity; H3 posited a negative relationship between Rebranding and Brand Equity; $\mathrm{H} 4$ posited a negative relationship between Perceived Quality and Brand Equity; H5 posited a negative relationship between Brand Attributes \& Associations and Brand Equity; while H6 and H7 posited a positive relationship between brand equity and firm's performance and customer experience and firm performance respectively. Consistent with $\mathrm{H} 6$ and $\mathrm{H} 7$, results indicated that higher levels of brand equity and customer experience will lead to higher levels of firm performance. Conversely, consistent with H3 and H4, rebranding efforts and perception of a quality outlet will not enhance the brand equity of an SME retail outlet. Similarly, consistent with H5, brand attributes and associations of the SME retail food outlet will neither influence nor enhance its brand equity. Thus, this confirms the statistical significance of all the posited relationships except $\mathrm{H} 2 ; \mathrm{H} 3 ; \mathrm{H} 4 ; \mathrm{H} 5$.

Table 3: Results of Structural Equation Model Analysis

\begin{tabular}{|l|c|c|c|c|}
\hline Proposed Hypothesis Relationship & Hypothesis & P-value & Significance & $\begin{array}{l}\text { Rejected / } \\
\text { Supported }\end{array}$ \\
\hline Store Layout (SL) $\rightarrow$ Rebranding (RB) & $\mathrm{H} 1$ & $* * *$ & Significant & Supported \\
\hline Franchising (F) $\rightarrow$ Rebranding (RB) & $\mathrm{H} 2$ & 0.830 & Insignificant & Reject \\
\hline Rebranding (RB) $\rightarrow$ Brand Equity (BE) & $\mathrm{H} 3$ & 0.208 & Insignificant & Reject \\
\hline $\begin{array}{l}\text { Perceived Quality (PQ) } \rightarrow \quad \text { Brand } \\
\text { Equity(BE) }\end{array}$ & $\mathrm{H} 4$ & 0.115 & Insignificant & Reject \\
\hline $\begin{array}{l}\text { Brand Attributes \& Associations (BAA) } \\
\rightarrow \text { Brand Equity (BE) }\end{array}$ & $\mathrm{H} 5$ & 0.197 & Insignificant & Reject \\
\hline $\begin{array}{l}\text { Brand Equity (BE) } \rightarrow \text { Firm Performance } \\
\text { (FM) }\end{array}$ & $\mathrm{H} 6$ & $* * *$ & Significant & Supported \\
\hline $\begin{array}{l}\text { Customer Experience (CE) F Firm } \\
\text { Performance (FP) }\end{array}$ & $\mathrm{H} 7$ & 0.001 & Significant & Supported \\
\hline
\end{tabular}

\subsection{Discussion and Conclusions}

$* * *=p$-value not provided but which is significant

The purpose of this study was to investigate the influence of rebranding, particularly Store Layout and Franchising, on brand equity and consequently, firm performance. In particular, seven hypotheses were postulated. To test the proposed hypotheses, data were collected from Gauteng Province in South Africa. The empirical results supported three out of seven posited research hypotheses in a significant way. Important to note about the study findings is the fact that Store layout has a stronger effect on rebranding efforts than franchising which is not supported. Perhaps the insignificant relationship between franchising and rebranding may be explained by the fact that consumers use the brand name and reputation as heuristic cues to infer a brand's quality and attributes (Delgado-Ballester, HernandezEspallardo \& Rodriguez-Orejuela, 2014). Rebranding disrupts the linkage between consumers and the original brand, and then substitutes it with the retail chain brand. If the renewed retail brand is associated with superior (inferior) quality compared with the original outlet, a consumer's intention to purchase is 
likely to increase (decrease). However, the relationship between rebranding and brand equity is not supported ( $p>0.208)$. This assertion is supported by extant literature which posits that there is a negative relationship between rebranding and brand equity (Petburikul, 2009; Roy \& Sarkar, 2015). Notably too, the relationship between brand attributes and associations and brand equity is not supported ( $\mathrm{p}>0.115)$.

Conversely, extant literature posits that brand equity and brand associations have an interconnection which generates a kind of driving force to customers (Keller, 2016). Perceived quality as well as brand attributes and association have no effect on brand equity with p> value: 0.115 and 0.197 respectively. However, brand equity and customer experience have a significant positive relationship with firm performance. By implication, this finding indicates that both brand equity and customer experience can have a strong influence on firm performance even if the organisation is not rebranded. In a retail setup or in-service industries, the interaction between customers and staff is likely to affect customers' shopping experience. Assistance from staff may leave a lasting impression that affects satisfaction, repeat buying, and financial performance. On the contrary, successful rebranding through store design intervention does not guarantee an increase in brand equity or firm performance.

\subsection{Implications}

The business world is increasingly competitive and sustaining the firm's brand equity is a colossal challenge for marketers. Many marketing researchers as well as practitioners emphasise the critical role of branding to affect brand equity and eventually enhance firm performance. Particularly marketing practitioners in South Africa are thus encouraged to adopt strategies that build and enhance brand equity of the business since this is likely to affect the firm performance. In order to build the brand equity, several brand communication strategies have to be adopted, such as brand promotions as well as brand advertisements. The current study is an attempt to investigate these relationships in an often-neglected context - the African context. Generally, the findings of this empirical study are expected to provide fruitful implications to both practitioners and academics.

From an academic perspective, this study makes a significant contribution to the brand management literature by systematically exploring the impact of layout interventions on rebranding; brand equity and customer experience on firm performance in South Africa. Largely, the current study findings provide tentative support to the proposition that brand equity and customer experience should be recognised as significant antecedents for gaining and sustaining firm performance in South Africa.

On marketing practitioners' perspective, the important influence of store layout, brand equity and customer experience in South Africa is highlighted. This study thus submits that marketers can benefit from the implications of these findings. Although the relationship between store layout and rebranding is significant, rebranding effort has no relationship with brand equity ( $p>$ Value 0.208 ). Store layouts that are well-designed are particularly significant because they strongly influence in-store traffic patterns, shopping atmosphere, shopping behaviour, and operational efficiency. Marketers, through the application of features of brand equity, create and stimulate customer attitude and cognition which subsequently influence their behaviour.

Conversely, rebranding through franchising and change in store layout does not influence the brand equity of the SME. This implies that rebranding is a risky operation that requires careful management. On the contrary, the relationship between brand equity and firm performance as well as customer experience and firm performance is significant. Overall, drawing from the research findings, one can put forward that theoretically, organisations tend to enhance firm performance only when their brand equity and customer experience is positive.

\subsection{Limitations and Future Research}

Regardless of the efficacy of this study, it has its limitations. Firstly, the study can be reinforced by increasing the sample size and including participants in other geographical areas. Secondly, the current study was limited to South Africa. For results' comparisons, subsequent researches should consider replicating this study in other developing countries. Finally, the present study did not examine such factors as brand identity, brand experience and brand trust. Future studies should focus on other antecedents and their potential effects on non-financial firm performance. Ceteris Paribus, all these recommended future opportunities of study stand to enormously contribute new knowledge to the 
existing body of brand management literature in Africa - a context that is often neglected by researchers in developing countries.

\section{References}

Aaker, D.A. and Joachimsthaler, E., 2000. The brand relationship spectrum: The key to the brand architecture challenge. California management review, 42(4), p.8.

Aaker, D.A., 1996. Measuring brand equity across products and markets. California management review, 38(3), p.102.

Abor, J. and Quartey, P., 2010. Issues in SME development in Ghana and South Africa. International research journal of finance and economics, 39(6), pp.215-228.

Aghekyan-Simonian, M., Forsythe, S., Kwon, W.S. and Chattaraman, V., 2012. The role of product brand image and online store image on perceived risks and online purchase intentions for apparel. Journal of Retailing and Consumer Services, 19(3), pp.325-331.

Al-Khouri, A.M., 2013. E-government in Arab countries: A 6-staged roadmap to develop the public sector. Journal of management and Strategy, 4(1), p.80.

Anderson, J.C. and Gerbing, D.W., 1988. Structural equation modeling in practice: A review and recommended twostep approach. Psychological bulletin, 103(3), p.411.

Bendixen, M., Bukasa, K.A. and Abratt, R., 2004. Brand equity in the business-to-business market. Industrial marketing management, 33(5), pp.371-380.

Beverland, M., Napoli, J. and Yakimova, R., 2007. Branding the business marketing offer: exploring brand attributes in business markets. Journal of Business \& Industrial Marketing, 22(6), pp.394-399.

Cameron, K.S. and Whetten, D.A. eds., 2013. Organizational effectiveness: A comparison of multiple models. New York: Academic Press.

Chin, W.W., 1998. Commentary: Issues and opinion on structural equation modeling. MIS Quarterly, 22(1), pp.7-16.

Cretu, A.E. and Brodie, R.J., 2007. The influence of brand image and company reputation where manufacturers market to small firms: A customer value perspective. Industrial Marketing Management, 36(2), pp.230-240.

Delgado-Ballester, E., Hernandez-Espallardo, M. and Rodriguez-Orejuela, A., 2014. Store image influences in consumers' perceptions of store brands: the moderating role of value consciousness. European Journal of Marketing, 48(9/10), pp.1850-1869.

Dixon, H., Niven, P., Scully, M. and Wakefield, M., 2017. Food marketing with movie character toys: Effects on young children's preferences for unhealthy and healthier fast food meals. Appetite, 117, pp.342-350.

Erenkol, A.D. and Duygun, A., 2010. Customers perceived brand equity and a research on the customers of Bellona which is a Turkish furniture brand. The Journal of American Academy of Business, 16(1), pp.93-109.

Farjam, S. and Hongyi, X., 2015. Reviewing the concept of brand equity and evaluating consumer-based brand equity (CBBE) models. International Journal of Management Science and Business Administration, 1(8), pp.14-29.

Fayrene, C.Y. and Lee, G.C., 2011. Customer-based brand equity: A literature review. Researchers World, 2(1), p.33.

Fornell, C. and Larcker, D.F., 1981. Structural equation models with unobservable variables and measurement error: Algebra and statistics. Journal of marketing research, pp.382-388.

Ghosh, P., Tripathi, V. and Kumar, A., 2010. Customer expectations of store attributes: A study of organized retail outlets in India. Journal of Retail \& Leisure Property, 9(1), pp.75-87.

Hanaysha, J., 2016. The importance of social media advertisements in enhancing brand equity: A study on fast food restaurant industry in Malaysia. International Journal of Innovation, Management and Technology, 7(2), p.46.

Hankinson, G., 2015. Rethinking the place branding construct. In Rethinking Place Branding (pp. 13-31). Berlin: Springer.

Harris, F. and De Chernatony, L., 2001. Corporate branding and corporate brand performance. European Journal of marketing, 35(3/4), pp.441-456.

Hutton, J.G., 1997. A study of brand equity in an organizational-buying context. Journal of Product \& Brand Management, 6(6), pp.428-439.

Jin, N., Lee, S. and Huffman, L., 2012. Impact of restaurant experience on brand image and customer loyalty: Moderating role of dining motivation. Journal of Travel \& Tourism Marketing, 29(6), pp.532-551.

Keller, K.L., 2003. Brand synthesis: The multidimensionality of brand knowledge. Journal of consumer research, 29(4), pp.595-600.

Keller, K.L., 2016. Reflections on customer-based brand equity: perspectives, progress, and priorities. AMS review, 6(12), pp.1-16.

Keller, K.L., 2017. Managing the growth tradeoff: Challenges and opportunities in luxury branding. In Advances in Luxury Brand Management (pp. 179-198). London: Palgrave Macmillan.

Kotler, P. and Keller, K., 2006. Marketing Management: Customer value, customer satisfaction and customer loyalty. Upper Saddle River, New Jersey: Pearson. 
Kwon, W.S. and Lennon, S.J., 2009. What induces online loyalty? Online versus offline brand images. Journal of Business Research, 62(5), pp.557-564.

Lee, C., Hallak, R. and Sardeshmukh, S.R., 2016. Innovation, entrepreneurship, and restaurant performance: A higherorder structural model. Tourism Management, 53, pp.215-228.

Lee, G.C. and Leh, F.C.Y., 2011. Dimensions of customer-based brand equity: A study on Malaysian brands. Journal of Marketing Research and Case Studies, 2011(10).

Maziriri, E. T., \& Chuchu, T. 2017. The Conception of Consumer Perceived Risk towards Online Purchases of Apparel and an Idiosyncratic Scrutiny of Perceived Social Risk: A Review of Literature. International Review of Management and Marketing, 7(3), pp. 257-265.

Maziriri, E. T., Mapuranga, M., \& Madinga, N. W. 2018. Self-service banking and financial literacy as prognosticators of business performance among rural small and medium-sized enterprises in Zimbabwe. The Southern African Journal of Entrepreneurship and Small Business Management, 10(1) pp., 1-10.

Meyer, C. and Schwager, A., 2007. Customer experience. Harvard business review, 85(2), pp.116-126.

Moisescu, O.I. and Vu, D.A., 2011. A conceptual review on building, managing and accessing brand loyalty. Review of Economic Studies and Research Virgil Madgearu, 4(1), p.67.

Muzellec, L. and Lambkin, M., 2006. Corporate rebranding: destroying, transferring or creating brand equity? European journal of marketing, 40(7/8), pp.803-824.

Nunnally, J.C. and Bernstein, I.H., 1994. The theory of measurement error. Psychometric theory, New York: McGrawHill, pp.209-247.

Opuni, F.F., Baffoe, M.S. and Adusei, E.P., 2013. The effectiveness of rebranding as a comparative study of Ghanaian business using the principles of corporate rebranding. Journal of Marketing and Management, 4(2), p.69.

Petburikul, K., 2009. The impact of corporate rebranding on brand equity and firm performance. RU International Journal, 3(1), pp.155-172.

Plewa, C., Lu, V. and Veale, R., 2011. The impact of rebranding on club member relationships. Asia Pacific Journal of Marketing and Logistics, 23(2), pp.222-242.

Ringle, C.M., Wende, S. and Will, S., 2005. SmartPLS 2.0 (M3). Hamburg: Beta.

Roy, S. and Sarkar, S., 2015. To brand or to rebrand: Investigating the effects of rebranding on brand equity and consumer attitudes. Journal of brand management, 22(4), pp.340-360.

Salinas, E.M. and Pérez, J.M.P., 2009. Modeling the brand extensions' influence on brand image. Journal of Business Research, 62(1), pp.50-60.

Saraswat, A., Mammen, T., Aagja, J.P. and Tewari, R., 2010. Building store brands using store image differentiation. Journal of Indian Business Research, 2(3), pp.166-180.

Schrempf, J., 2014. A social connection approach to corporate responsibility: The case of the fast-food industry and obesity. Business \& Society, 53(2), pp.300-332.

Wali, A.F., Wright, L.T. and Uduma, I.A., 2015. Customer relationship management for brand commitment and brand loyalty. British Journal of Marketing Studies, 3(4), pp.45-58 